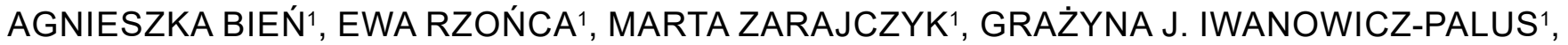 AGNIESZKA KOZAK ${ }^{2}$
}

\section{The role of the media in the promotion of breastfeeding}

\begin{abstract}
Introduction. Breastfeeding is the optimal method of nourishing newborns and infants, as provided in guidelines and recommendations issued by both maternal and child health organizations and associations. For this reason, breastfeeding should be promoted and supported through educating the population. Various media outlets (television, radio, the Internet, press) have become an integral part of people's daily life and an important source of information on health.

Aim. The present study aimed at determining the role of the mass media in the promotion of breastfeeding.

Material and methods. The study was conducted between January and April 2015 on 262 women. The study used a diagnostic survey with questionnaires. The researchers used a self-designed questionnaire. The software used for databases and statistical analysis was STATISTICA 9.1 (StatSoft, Poland).

Results. A statistical analysis has shown that married women $(p=0.00168)$, women with higher education $(p=0.04007)$, women who had their own businesses $(\mathrm{p}=0.04482)$ and those who had given birth to one child $(\mathrm{p}=0.00093)$ stated that information on breastfeeding was available in the media. The women surveyed pointed to the media (56.13\%) as the source of information on breastfeeding, while the Internet $(82.07 \%)$ was the most popular medium used by the respondents to look for information on breastfeeding. The participants believed that the media should focus on promoting the benefits of breastfeeding for the child $(94.27 \%)$.

Conclusions. The media are the most popular source of information on breastfeeding. The media should promote breastfeeding mainly through providing information on the benefits for the child. The Internet is the most popular medium to look for information on breastfeeding.
\end{abstract}

Keywords: media, breastfeeding, health promotion.

DOI: $10.1515 /$ pjph-2016-0021

\section{INTRODUCTION}

Breastfeeding is the optimum method of feeding newborns and infants, following the guidelines and recommendations issued by maternal and child health organizations and associations. It is highly beneficial, both directly and indirectly, for the child and the mother [1-5]. Although the number of breast-fed children in developed countries decreased significantly in the $20^{\text {th }}$ century, the situation has been improving since the 1970s [2,6,7]. It is necessary, therefore, to further promote and support breastfeeding through education [1,5-8]. Cooperation with the media appears crucial for increasing the effectiveness of such efforts [8-11]. The media (television, radio, the Internet, press) have become an integral part of people's daily life, providing opportunities for development by finding and using information. The media are also an important source of information on health and thus they influence people's lifestyle and health behaviors [9-11].

\section{AIM}

The present study aimed at determining the role of mass media in the promotion of breastfeeding.

\section{MATERIAL AND METHODS}

The study was conducted between January and April 2015 on 262 women (pregnant/post-partum, aged over 18 years) all patients of Pregnancy Pathology and Maternity-Neonatal Departments at Cardinal Stefan Wyszyński Regional Specialist Hospital in Lublin. The study was approved by the Bioethics Committee of the Medical University of Lublin (KE0254/336/2014). The participants were informed that their participation was voluntary, the protection of their anonymity, as well as the fact that the findings will be used for scientific purposes only.

We used the diagnostic poll method based on self-designed survey questionnaire. It included questions concerning sociodemographic data on the participants and the subject of the study.

\footnotetext{
${ }^{1}$ Department of the Basics of Midwifery, Faculty of Health Sciences, Medical University of Lublin, Poland

${ }^{2}$ Student Research Group of the Department of the Basics of Midwifery, Faculty of Health Sciences, Medical University of Lublin, Poland
} 
The results obtained were statistically analyzed. The software used for databases and statistical analyses was STATISTICA 9.1 (StatSoft, Poland). The qualitative parameters analyzed were presented as numbers and percentages. The $\chi^{2}$ test was used for qualitative parameters to establish correlations between the analyzed variables. Statistical significance was set at $\mathrm{p}<0.05$.

\section{RESULTS}

The majority of women surveyed were aged less than 25 $(32.44 \%)$, were city residents $(57.25 \%)$, had higher education $(69.84 \%)$, were married $(66.03 \%)$, worked in the public sector (38.93\%) and were pregnant (39.31\%) - Table 1 .

Table 2 presents the respondents' opinions about the sources of information on breastfeeding. The women were most likely to mention the media $(56.13 \%)$, their family or close friends $(54.84 \%)$ and specialist literature $(52.90 \%)$, while the Internet $(82.07 \%)$ was the most popular medium used by the respondents to search for information on breastfeeding. The participants believed that the media should focus on promoting the benefits of breastfeeding for the child (94.27\%), while medical staff should be the main source of information on breastfeeding positions (58.71\%), teaching effective latching onto the breast $(76.77 \%)$ and solving problems related to lactation period $(69.03 \%)$.

Table 3 contains information on the correlation between the respondents' opinion about the availability of breastfeeding information in the media and the socio-demographic data. A statistical analysis has revealed that married women $(p=0.00168)$, women with higher education $(\mathrm{p}=0.04007)$, women who had their own businesses $(p=0.04482)$ and those who had given birth to one child $(\mathrm{p}=0.00093)$ stated that information on breastfeeding was available in the media. No statistically significant correlation was found between the participants' opinion on this subject and their age or place of residence $(\mathrm{p}>0.05)$.

TABLE 1. Characteristics of study participants.

\begin{tabular}{|c|c|c|c|}
\hline \multicolumn{2}{|c|}{ Socio-demographic data } & \multirow{2}{*}{$\begin{array}{l}\mathbf{N} \\
85\end{array}$} & \multirow{2}{*}{$\begin{array}{c}\% \\
32.44 \\
\end{array}$} \\
\hline \multirow{4}{*}{ Age } & $<25$ & & \\
\hline & $26-30$ & 77 & 29.39 \\
\hline & $31-35$ & 56 & 21.37 \\
\hline & $>36$ & 44 & 16.80 \\
\hline \multirow{3}{*}{ Place of residence } & city & 150 & 57.25 \\
\hline & town & 53 & 20.23 \\
\hline & countryside & 59 & 22.52 \\
\hline \multirow{2}{*}{ Education } & higher & 183 & 69.84 \\
\hline & vocational/secondary school & 79 & 30.16 \\
\hline \multirow{2}{*}{ Marital status } & married & 173 & 66.03 \\
\hline & single & 89 & 33.97 \\
\hline \multirow{5}{*}{ Professional activity } & student & 61 & 23.29 \\
\hline & public sector employee & 102 & 38.93 \\
\hline & private sector employee & 59 & 22.51 \\
\hline & own business & 25 & 9.54 \\
\hline & unemployed & 15 & 5.73 \\
\hline \multirow{3}{*}{ Childbirths } & none/pregnancy & 103 & 39.31 \\
\hline & 1 child & 81 & 30.91 \\
\hline & 2 or more children & 78 & 29.78 \\
\hline
\end{tabular}

Table 4 presents the correlation between the respondents' opinion on whether the media should promote breastfeeding and their opinion on the promotion of breastfeeding in the media and socio-demographic data. The opinion that the media should promote breastfeeding was most popular among women aged 31-35 $(p=0.01524)$, married women $(p=0.00548)$, women working in the private sector $(\mathrm{p}=0.00042)$ and those who had given birth to at least one child $(\mathrm{p}=0.03877)$. No statistically significant correlation was found between the participants' opinion on this subject and their place of residence or education $(\mathrm{p}>0.05)$. The second part of the analysis showed that it was mainly women aged $31-35(\mathrm{p}=0.00755)$, married $(\mathrm{p}=0.00000)$, with higher education $(\mathrm{p}=0.02925)$, unemployed $(p=0.00839)$ and those who had given birth to two or more children $(p=0.00001)$ who believed that the media promote breastfeeding. We have not noticed any statistically significant differences between this opinion and the place of residence $(\mathrm{p}>0.05)$.

The analysis has revealed a statistically significant correlation between the choice of the type of media regarding information on breastfeeding and the age of the participants

TABLE 2. The respondents' opinion on selected aspects of breastfeeding.

\begin{tabular}{|c|c|c|}
\hline \multicolumn{2}{|c|}{ The respondents' opinion on selected aspects of breastfeeding } & $\%$ \\
\hline \multirow{5}{*}{$\begin{array}{l}\text { Sources of information } \\
\text { on breastfeeding }\end{array}$} & media & 56.13 \\
\hline & family/close friends & 54.84 \\
\hline & specialist literature & 52.90 \\
\hline & medical personnel on ward & 48.39 \\
\hline & antenatal classes & 25.81 \\
\hline \multirow{4}{*}{$\begin{array}{l}\text { Type of media providing } \\
\text { information on breastfeeding }\end{array}$} & the Internet & 82.07 \\
\hline & press & 12.73 \\
\hline & television & 4.73 \\
\hline & radio & 0.47 \\
\hline \multirow{4}{*}{$\begin{array}{l}\text { Information which should be } \\
\text { disseminated by the media } \\
\text { to promote breastfeeding* }\end{array}$} & $\begin{array}{l}\text { information on benefits } \\
\text { for the child }\end{array}$ & 94.27 \\
\hline & $\begin{array}{l}\text { information on the development } \\
\text { of a bond between the mother } \\
\text { and the child }\end{array}$ & 75.57 \\
\hline & $\begin{array}{l}\text { information on benefits } \\
\text { for the mother }\end{array}$ & 74.81 \\
\hline & $\begin{array}{l}\text { information on financial } \\
\text { benefits }\end{array}$ & 56.87 \\
\hline \multirow{5}{*}{$\begin{array}{l}\text { Source of information } \\
\text { on breastfeeding positions* }\end{array}$} & medical personnel on ward & 58.71 \\
\hline & books & 40.65 \\
\hline & media & 37.42 \\
\hline & family/friends & 30.32 \\
\hline & antenatal classes & 21.29 \\
\hline \multirow{5}{*}{$\begin{array}{l}\text { Source of information teach- } \\
\text { ing the most effective } \\
\text { latching methods }\end{array}$} & medical staff on ward & 76.77 \\
\hline & books & 3.87 \\
\hline & media & 3.23 \\
\hline & family/friends & 9.67 \\
\hline & antenatal classes & 6.46 \\
\hline \multirow{5}{*}{$\begin{array}{l}\text { Sources of information } \\
\text { on solving problems related } \\
\text { to lactation period }\end{array}$} & medical staff on ward & 69.03 \\
\hline & books & 22.58 \\
\hline & media & 35.48 \\
\hline & family/friends & 38.06 \\
\hline & antenatal classes & 7.40 \\
\hline
\end{tabular}

* the total sum of values is not $100 \%$ due to the possibility of multiple choice 
$(\mathrm{p}=0.00000)$. The Internet was the main place that respondents of all ages, looking for information on breastfeeding, used (Table 5). No statistically significant differences were found between this aspect and other socio-demographic factors: place of residence, education, marital status, professional activity, and the number of given births $(\mathrm{p}>0.05)$.

\section{DISCUSSION}

Data on the EU Member States published in 2015 reveals that only in a few countries, such as Malta, Slovakia, Portugal and Hungary, the percentage of children who are breast-fed for 6 months exceeds $30 \%$. In other countries, the percentage of breastfeeding mothers is much lower. Although in many countries $70-90 \%$ of mothers declare shortly after giving birth that they intend to breast-feed, over time the percentage of breastfeeding mothers decreases dramatically [6]. These unsatisfactory reports clearly show a need for an active promotion of breastfeeding, both in Poland and around the world. Over the recent years, mass media have become an educational tool, playing an important role in promoting health, including reproductive health [10]. In our study, the media emerged to be the most popular $(56.13 \%)$ source of information on breastfeeding for women during the perinatal period. Most participants used the Internet to expand their knowledge on the subject (82.07\%). However, the study by Klejewski et al. demonstrated that the most popular source of information on breastfeeding for women were books and guidebooks, which were indicated by over a half of the participants (64.35\%). Midwives were the second most popular source of information $(54.45 \%)$, while the media were mentioned by half of the respondents $(50.49 \%)$ [4]. It is noticeable that both in our study and other authors' research, reliable sources of information on breastfeeding, such as medical staff or antenatal classes were mentioned less frequently $[4,12]$.

TABLE 3. Correlation between the respondents' opinion whether information on breastfeeding was available in the media and sociodemographic data.

\begin{tabular}{|c|c|c|c|c|c|}
\hline \multirow{3}{*}{ Socio-demographic data } & \multicolumn{4}{|c|}{ Information in the media } & \multirow{3}{*}{$\begin{array}{l}\text { Statistical } \\
\text { analysis }\end{array}$} \\
\hline & \multicolumn{2}{|c|}{ yes } & \multicolumn{2}{|c|}{ no } & \\
\hline & $\mathbf{N}$ & $\%$ & $\mathbf{N}$ & $\%$ & \\
\hline \multicolumn{5}{|l|}{ Marital status } & \multirow{3}{*}{$\begin{array}{c}\chi^{2}=9.866929 \\
\mathbf{p}=\mathbf{0 . 0 0 1 6 8}\end{array}$} \\
\hline single & 58 & 65.17 & 31 & 34.83 & \\
\hline married & 144 & 83.24 & 29 & 16.76 & \\
\hline \multicolumn{5}{|l|}{ Education } & \multirow{3}{*}{$\begin{array}{c}\chi^{2}=4.215236 \\
\mathbf{p}=\mathbf{0 . 0 4 0 0 7}\end{array}$} \\
\hline vocational/secondary school & 54 & 68.35 & 25 & 31.65 & \\
\hline higher & 148 & 80.87 & 35 & 19.13 & \\
\hline \multicolumn{5}{|l|}{ Professional activity } & \multirow{6}{*}{$\begin{array}{c}\chi^{2}=9.752279 \\
\mathbf{p}=\mathbf{0 . 0 4 4 8 2}\end{array}$} \\
\hline student & 44 & 72.13 & 17 & 27.87 & \\
\hline public sector employee & 73 & 71.57 & 29 & 28.43 & \\
\hline private sector employee & 50 & 84.75 & 9 & 15.25 & \\
\hline own business & 24 & 96.00 & 1 & 4.00 & \\
\hline unemployed & 11 & 73.33 & 4 & 26.67 & \\
\hline \multicolumn{5}{|l|}{ Childbirths } & \multirow{4}{*}{$\begin{array}{c}\chi^{2}=13.96666 \\
\mathbf{p}=\mathbf{0 . 0 0 0 9 3}\end{array}$} \\
\hline none/pregnancy & 67 & 65.05 & 36 & 34.95 & \\
\hline 1 child & 69 & 85.19 & 12 & 14.81 & \\
\hline 2 or more children & 66 & 84.62 & 12 & 15.38 & \\
\hline
\end{tabular}

Providing knowledge on the benefits, advantages and methods of dealing with problems during the lactation period as well as offering women support and assistance during breastfeeding should be prioritized in order to strengthen the role of breastfeeding in society, increase the number of breastfeeding mothers and extend the breastfeeding period [1]. The study has shown that the participants were most interested in the information

TABLE 4. Correlation between the respondents' opinion on whether the media should promote breastfeeding and their opinion on promoting breastfeeding by the media, and socio-demographic data.

\begin{tabular}{|c|c|c|c|c|c|}
\hline \multirow{3}{*}{ Socio-demographic data } & \multicolumn{4}{|c|}{$\begin{array}{l}\text { The media should promote } \\
\text { breastfeeding }\end{array}$} & \multirow{3}{*}{$\begin{array}{l}\text { Statistical } \\
\text { analysis }\end{array}$} \\
\hline & \multicolumn{2}{|c|}{ yes } & \multicolumn{2}{|c|}{ no } & \\
\hline & $\mathbf{N}$ & $\%$ & $\mathbf{N}$ & $\%$ & \\
\hline \multicolumn{5}{|l|}{ Age } & \multirow{5}{*}{$\begin{array}{l}\chi^{2}=10.4311 \\
\mathbf{p}=\mathbf{0 . 0 1 5 2 4}\end{array}$} \\
\hline$<25$ & 74 & 87.06 & 11 & 12.94 & \\
\hline $26-30$ & 74 & 96.10 & 3 & 3.90 & \\
\hline $31-35$ & 56 & 100.00 & 0 & 0.00 & \\
\hline$>36$ & 40 & 90.91 & 4 & 9.09 & \\
\hline \multicolumn{5}{|l|}{ Marital status } & \multirow{3}{*}{$\begin{array}{l}\chi^{2}=7.71359 \\
\mathbf{p}=\mathbf{0 . 0 0 5 4 8}\end{array}$} \\
\hline single & 77 & 86.52 & 12 & 13.48 & \\
\hline married & 167 & 96.53 & 6 & 3.47 & \\
\hline \multicolumn{5}{|l|}{ Professional activity } & \multirow{6}{*}{$\begin{array}{l}\chi^{2}=20.3662 \\
\mathbf{p}=\mathbf{0 . 0 0 0 4 2}\end{array}$} \\
\hline student & 52 & 85.25 & 9 & 14.75 & \\
\hline public sector employee & 99 & 97.06 & 3 & 2.94 & \\
\hline private sector employee & 58 & 98.31 & 1 & 1.69 & \\
\hline own business & 24 & 96.00 & 1 & 4.00 & \\
\hline unemployed & 11 & 73.33 & 4 & 26.67 & \\
\hline \multicolumn{5}{|l|}{ Childbirths } & \multirow{4}{*}{$\begin{aligned} \chi^{2} & =6.500674 \\
\mathbf{p} & =\mathbf{0 . 0 3 8 7 7}\end{aligned}$} \\
\hline none/pregnancy & 91 & 88.35 & 12 & 11.65 & \\
\hline 1 child & 79 & 97.53 & 2 & 2.47 & \\
\hline 2 or more children & 74 & 94.87 & 4 & 5.13 & \\
\hline
\end{tabular}

\begin{tabular}{|c|c|c|c|c|c|}
\hline \multicolumn{5}{|l|}{ Age } & \multirow{5}{*}{$\begin{array}{c}\chi^{2}=11.95183 \\
\mathbf{p}=\mathbf{0 . 0 0 7 5 5}\end{array}$} \\
\hline$<25$ & 29 & 34.12 & 56 & 65.88 & \\
\hline $26-30$ & 40 & 51.95 & 37 & 48.05 & \\
\hline $31-35$ & 34 & 60.71 & 22 & 39.29 & \\
\hline$>36$ & 25 & 56.82 & 19 & 43.18 & \\
\hline \multicolumn{5}{|c|}{ Marital status } & \multirow{3}{*}{$\begin{array}{c}\chi^{2}=22.01794 \\
\mathbf{p}=\mathbf{0 . 0 0 0 0 0}\end{array}$} \\
\hline single & 25 & 28.09 & 64 & 71.91 & \\
\hline married & 103 & 59.54 & 70 & 40.46 & \\
\hline
\end{tabular}

\begin{tabular}{|c|c|c|c|c|c|}
\hline \multicolumn{5}{|l|}{ Education } & \multirow{3}{*}{$\begin{array}{c}\chi^{2}=4.753239 \\
\mathbf{p}=\mathbf{0 . 0 2 9 2 5}\end{array}$} \\
\hline vocational/secondary school & 30 & 37.97 & 49 & 62.03 & \\
\hline higher & 98 & 53.55 & 85 & 46.45 & \\
\hline
\end{tabular}

\begin{tabular}{|c|c|c|c|c|c|}
\hline \multicolumn{5}{|l|}{ Professional activity } & \multirow{6}{*}{$\begin{array}{c}\chi^{2}=13.67979 \\
\mathbf{p}=\mathbf{0 . 0 0 8 3 9}\end{array}$} \\
\hline student & 21 & 34.43 & 40 & 65.57 & \\
\hline public sector employee & 45 & 44.12 & 57 & 55.88 & \\
\hline private sector employee & 37 & 62.71 & 22 & 37.29 & \\
\hline own business & 15 & 60.00 & 10 & 40.00 & \\
\hline unemployed & 10 & 66.67 & 5 & 33.33 & \\
\hline \multicolumn{5}{|l|}{ Childbirths } & \multirow{4}{*}{$\begin{array}{c}\chi^{2}=23.02628 \\
\mathbf{p}=\mathbf{0 . 0 0 0 0 1}\end{array}$} \\
\hline none/pregnancy & 32 & 31.07 & 71 & 68.93 & \\
\hline 1 child & 45 & 55.56 & 36 & 44.44 & \\
\hline 2 or more children & 51 & 65.38 & 27 & 34.62 & \\
\hline
\end{tabular}


TABLE 5. Correlation between the choice of different types of media in search for information on breastfeeding and the age of the participants.

\begin{tabular}{|c|c|c|c|c|c|c|c|}
\hline \multirow{3}{*}{ Age } & \multicolumn{6}{|c|}{ Mass media } & \multirow{3}{*}{$\begin{array}{l}\text { Statistical } \\
\text { analysis }\end{array}$} \\
\hline & \multicolumn{2}{|c|}{ press } & \multicolumn{2}{|c|}{ television } & \multicolumn{2}{|c|}{ the Internet } & \\
\hline & $\mathbf{N}$ & $\%$ & $\mathbf{N}$ & $\%$ & $\mathbf{N}$ & $\%$ & \\
\hline$<25$ & 5 & 7.14 & 0 & 0.00 & 65 & 92.86 & \multirow{4}{*}{$\begin{array}{c}\chi^{2}=30.19246 \\
\mathbf{p}=\mathbf{0 . 0 0 0 0 0}\end{array}$} \\
\hline $26-30$ & 6 & 9.68 & 3 & 4.84 & 53 & 85.48 & \\
\hline $31-35$ & 3 & 6.67 & 5 & 11.11 & 37 & 82.22 & \\
\hline$>36$ & 13 & 37.14 & 3 & 8.57 & 19 & 54.29 & \\
\hline
\end{tabular}

on the benefits of breastfeeding for the child (94.27\%), creating a bond between the mother and the child (75.57\%) and benefits for the mother (74.81\%).

Similarly to the countries of the West, the Polish society has become an information society and this change is visible mostly among young people [13]. This was also confirmed by the results of our study, which showed that the youngest participants obtained information on breastfeeding primarily from the media and that the Internet was the most popular source of information for this age group $(92.86 \%)$.

The media's capability of spreading information in an attractive way might be used for promoting campaigns, stimulating social expectations and shaping new behavioral patterns [14]. The participants generally believed that the media should promote breastfeeding. Women aged 31-35, married women, working women and those who had given birth to one child $(\mathrm{p}<0.05)$ were most likely to hold such an opinion.

It is of utmost importance that information which parents gain from the mass media is reliable and based on the current state of knowledge on the subject. It is beneficial for parents to obtain the information from specialists or from magazines and websites edited by health care professionals. Mindful motherhood requires acquiring knowledge and skills on self-care during the perinatal period, including information on breastfeeding [15]. Interestingly enough, our research has shown that medical professionals were always chosen by the participants as the primary source of the specific information on breastfeeding, including breastfeeding positions, effective latching or solving problems during the lactation period.

It is still necessary to develop effective methods to promote breastfeeding, which would help to shape the right attitudes among the society, bring the prestige to breastfeeding and educate women so that they treat breastfeeding as a natural activity at a certain stage of their lives.

\section{CONCLUSIONS}

1. The media are the most popular source of information on breastfeeding.

2. The Internet is the most popular medium providing information on breastfeeding.

3. Medical staff should become the main source of information on breastfeeding positions, effective latching methods and solving problems that occur in the lactation period.

4. The media should promote breastfeeding mainly through providing information on the benefits for the child.

\section{REFERENCES}

1. Florea M. Laktacja i karmienie piersią. Przegląd piśmiennictwa. Perinatol Neonatol Ginekol. 2014;7(3):165-70.

2. Kowalska ME, Kalinowski P, Bojakowska U. Perspektywa globalna i krajowa edukacji kobiet w zakresie karmienia naturalnego. Pielęg XXIw. 2013;1(42):49-52

3. Ćwiek D, Branecka-Woźniak D, Fryc D, et al. Reasons for giving up breastfeeding and support during problems with lactation in the northwestern part of Poland. Ann Acad Med Stetin. 2010;56(2):129-32.

4. Klejewski A, Urbaniak T, Bączyk G, Cichocka E. Wiedza o zaletach karmienia naturalnego wśród kobiet rodzących pierwsze dziecko. Prz Lek. 2012;69(10):1021-5.

5. Cierpka A, Żuralska R, Olszewski J, Gaworska-Krzemińska A. Wiedza położnic na temat karmienia piersią. Probl Pielęg. 2007;15(2,3):172-8.

6. Bagci Bosi AT, Eriksen KG, Sobko T, et al. Breastfeeding practices and policies in WHO European Region Member States. Public Health Nutr. 2015;22:1-12.

7. Foss KA, Southwell BG. Infant feeding and the media: the relationship between Parents' Magazine content and breastfeeding, 1972-2000. Int Breastfeed J. 2006;1:10. doi:10.1186/1746-4358-1-10.

8. Rozporządzenie Rady Ministrów z dnia 4 sierpnia 2016 r. w sprawie Narodowego Programu Zdrowia na lata 2016-2020 (Dz. U. poz. 1492).

9. Syrkiewicz-Świtała M, Holecki T, Wojtynek E. Znaczenie mass mediów w promocji zdrowia. Med Og Nauk Zdr. 2014;20(2):171-6.

10. Szymczuk E, Zajchowska J, Dominik A, et al. Media jako źródło wiedzy o zdrowiu. Med Og Nauk Zdr. 2011;17(4):165-8.

11. Wojciechowska M, Roda M. Rola prasy w promocji zdrowia. Hygeia Public Health 2015;50(2):401-5.

12. Gawęda A, Woś H. Karmienie naturalne oraz czynniki warunkujące jego długość u dzieci z terenu Górnego Śląska. Nowa Pediatr. 2007;1(5):5-10.

13. Turbiarz A, Kadłubowska M, Kolonko J, Bąk E. Rola mediów w promocji zdrowia. Probl Pielęg. 2010;18(2):239-42.

14. Kozłowska A. Oddziaływanie mass mediów. Warszawa: Szkoła Główna Handlowa w Warszawie; 2006. p.111.

15. Deluga A, Olkuska E, Ślusarska B. Wiedza rodziców na temat okresu noworodkowego i ich oczekiwania wobec pielęgniarek i położnych. Med Og Nauk Zdr. 2012;18(4):281-6.

\section{Corresponding author}

Agnieszka Bien

Medical University of Lublin, Faculty of Health Sciences

Staszica 4-6 Str., 20-081 Lublin

E-mail: agnesmbien@gmail.com 